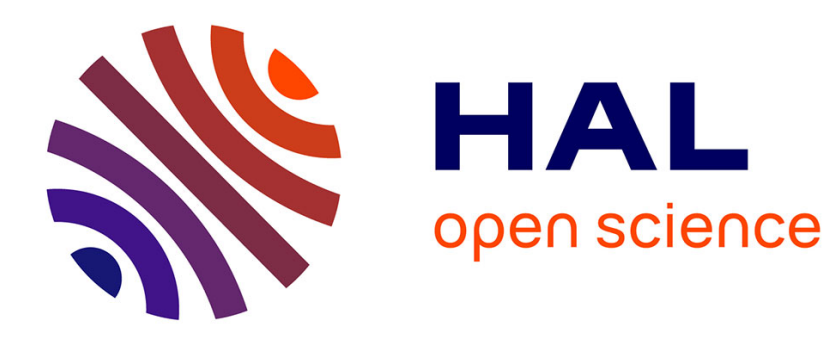

\title{
Studies of laser induced-MOCVD zinc oxide films
}

Z. Tan, P. Ren, W. Luo

\section{To cite this version:}

Z. Tan, P. Ren, W. Luo. Studies of laser induced-MOCVD zinc oxide films. Journal de Physique IV Proceedings, 1993, 03 (C3), pp.C3-261-C3-264. 10.1051/jp4:1993335 . jpa-00251392

\section{HAL Id: jpa-00251392 https://hal.science/jpa-00251392}

Submitted on 1 Jan 1993

HAL is a multi-disciplinary open access archive for the deposit and dissemination of scientific research documents, whether they are published or not. The documents may come from teaching and research institutions in France or abroad, or from public or private research centers.
L'archive ouverte pluridisciplinaire HAL, est destinée au dépôt et à la diffusion de documents scientifiques de niveau recherche, publiés ou non, émanant des établissements d'enseignement et de recherche français ou étrangers, des laboratoires publics ou privés. 


\title{
Studies of laser induced-MOCVD zinc oxide films
}

\author{
Z. TAN, P. REN and W. LUO
}

Center for Functional Materials Research, Qingdao Institute of Chemical Technology, Qingdao 266042, China

\begin{abstract}
Thin films of Zn0 have been prepared by the double photobeams ultraviolet laser induced-metallorganic chemical vapour deposition (MOCVD) technique. The structure and transparent photoconductive property of these films are investigated by $X$-ray diffraction $(X R D)$, reflecting electron diffraction( RED), scanning electron microscopy ( $S E M$ ) and ultraviolet visible absorption spectrometry(UV). The experiment shows that the technique produces superior quality films of polycrystal $Z n 0$ and possesses higher deposition rate, lower temperature of growth and far better transparent photoconductive property than those grown by the conventional CUD or MOCVD technique.
\end{abstract}

\section{1 - INTRODUCTION}

Zinc oxide $(\mathrm{ZnO})$ in pure form is a $n$-type semiconductor with wide band gaps near 3. 3ev, with large piezoelectric and optical coupling constants. Thin films of $2 n 0$ with high conductivity and optical transparency have been applied to solar cells $[1,2]$, surface acoustic wave devices [3], transparent conducting materials [4], and gas sensors [5]. A variety of techniques, including sputering[6], chemical vapor deposition (CVD) [7], and metallorganic -CVD technique(MOCVD) [8,9]. To obtain uniform films of $\mathrm{ZnO}$ at high deposition rates and low temperature of growth, we have studied laser induced MocvD technique with double-beams. The transparent photoconductive property of these films are reported in this paper.

\section{2-EXPER IMENTS}

The experimental arrangement for photodepositing the $2 n 0$ film is shown in Fig.1. 


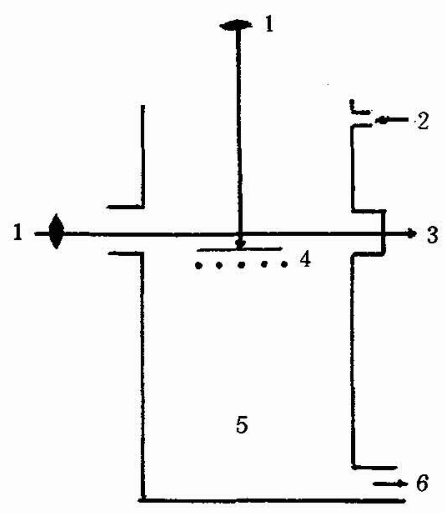

Fig.1 Experimental arrangement: 1.photon source 2.reactant gases 3. power meter 4.substrate 5.reactor 6.to vacuum pump

Using purity dimethyl zinc(DMZ) as a zinc source He-NzO mixture as the carrier gas, excimer laser $\lambda=266 \mathrm{~nm}$ as photon source, the pressure in the reactor is 2 Torr, on glass and mica substrates, at room temperature to $240^{\circ} \mathrm{C}$. The substrate is placed on a temperature controlled heater. The nonstoichiometric(0xygen-deficied) zinc oxide $\left(\mathrm{ZnO}_{1-\mathrm{x}}\right)$ polycrystalline films are formed when the temperature of the substrate is between $80-240^{\circ} \mathrm{C}$. The irradiation of focused laser beam paralled and perpendicular to substrate surface. These $2 n 0_{1-x}$ films (thickness $50 \sim 200 \mathrm{~nm}$ ) with lower resistivities and higher optical transmission are obtained at deposition rate $300 \mathrm{~nm} / \mathrm{min}$. The films are characterized by SEM. RED and UV spectrometry. The results are shown in the Fig.2.3.4. The opposite intensity of XRD line are listed in table 1 .

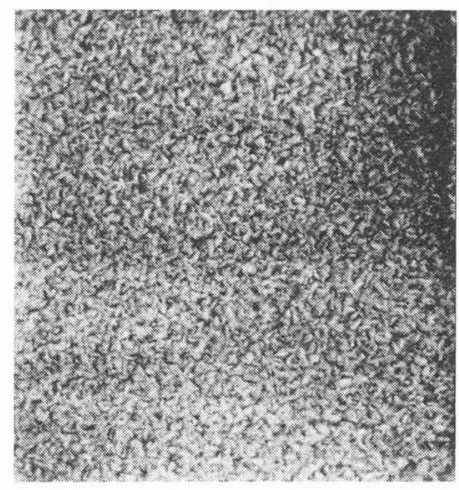

(a)

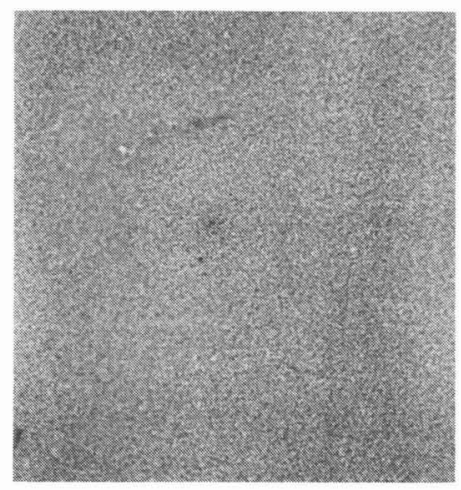

(b) 
Fig. 2 SEM morphology $(X 5.00 K)$ of $\mathrm{ZnO}$ films on (111) single crystal silicon (a) grown at $220^{\circ} \mathrm{C}$; (b) grown at $420^{\circ} \mathrm{C}$

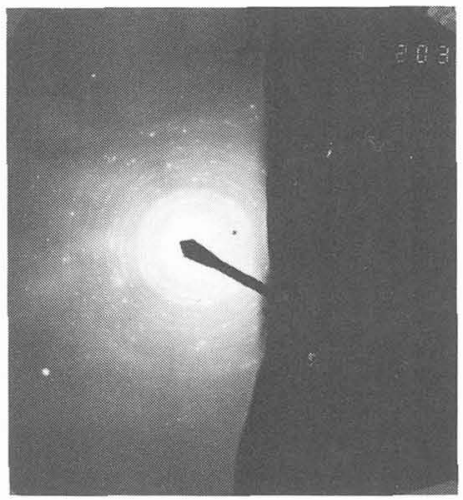

(a)

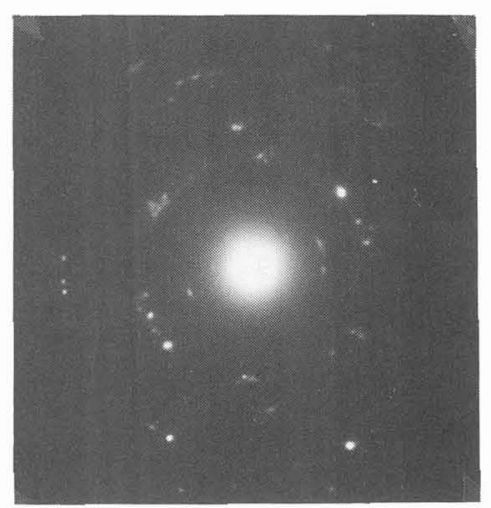

(b)

Fig. 3 RED morphology of Zno films on (111) single crystal silicon at $220^{\circ} \mathrm{C}$. (a) polycrystaline diffractive ring; (b) the direction of the $\mathrm{C}-\mathrm{ax}$ is

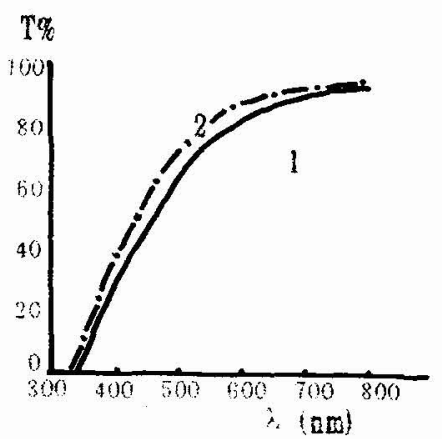

Fig. 4 The UV absorption spec rum 1--deposition rate $230 \mathrm{~nm} / \mathrm{min}$ 2--deposition rate $200 \mathrm{~nm} /$ min
$\operatorname{Ris} \Omega \mathrm{cm}^{2}$

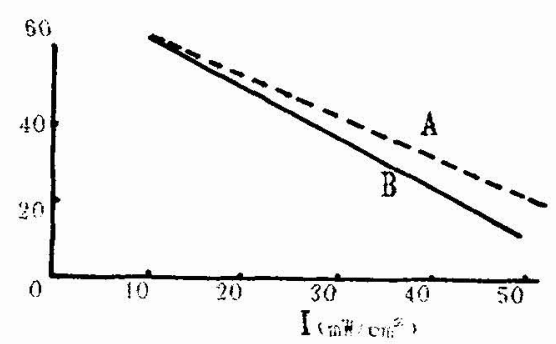

Fig. 5 The photoconductivity of Zno films (thinkness $150 \mathrm{~nm}$ ) A--deposition rate $230 \mathrm{~nm} / \mathrm{min}$ B--deposition rate $200 \mathrm{~nm} / \mathrm{min}$ 
TABLE 1. The opposite intensity of XRD lines

\begin{tabular}{|l|l|l|l|l|l|l|}
\hline \multirow{2}{*}{ substrates* } & \multicolumn{3}{|c|}{ XRD line opposite indensity } \\
\hline & pyre & 100 & 002 & 101 & 102 & 103 \\
\hline & 0.04 & 1 & 0.02 & 0.06 & 0.09 \\
\hline & mica** & 0.02 & 1 & 0.01 & 0.03 & 0.05 \\
\hline
\end{tabular}

* substrates temperature $220^{\circ} \mathrm{C}$

** direction $\langle 001\rangle$ of the mica

\section{3-CONCLUSIONS}

The electron diffraction experiment indicates that laser induce MOCVD technique can produce uniform films at a high deposition rate $(300 \mathrm{~nm} / \mathrm{min}) \mathrm{Fig.2}$. The maximum crystal orientation is along $\mathrm{C}$-axis, the temperature range is $80-240 \mathrm{C}$ and the best structural perfection is obtained on mica substrate and the growing direction of Zno suits mica(Fig.3 and table 1). These films are always characterized by the presence of (002) as the strongest line (table 1$)$. The Zno films obtained by laser-induced MOCVD technique possess far better transparent photoconductive property (Fig.4-5), higher deposition rate and lower temperature of growth than obtained by other methods.

\section{REFERENCE}

[1] MENNER R., DIMMLER B., MAUCH R.H. and SCHOCK H.W., J.Cryst.Growth $86(1988) 906$.

[2] YOO J.B.,FAHRENBRUCH A.L, , and BUBE R.H., J.Appl.Phys. 68(1990) 4694.

[3] LEE C.T., SU Y.K. and CHEN S.L., J.Cryst.Growth 96(1989)785.

[4] IGASAKI Y.and SAITO H., J.Appl. Phys. 70(1991)3613.

[5] PIZZINI S.,BUTTA N., NARDUCCI D. and PALLADIND M., J.Electrochem.Soc. $136(1989) 1945$.

[6] BANERJEE A., WOLF D., YANG J. and GUHA S., J.Appl.Phys. 70(1991)1692.

[7] SHIMIZU M., SHIOSAKI T. and KAWABATA A., J.Cryst.Growth 57(1982)94.

[8] SOULETIE P.,BETHKE S., WESSELS B.W. and PAN H., J.Cryst.Growth $86(1988) 248$.

[9] KIM J.S., MARZOUK H.A., REUCROFT P.J. and HAMRIN C.E., Thin Solid Films $217(1992) 133$. 